\section{ECONOMICS}

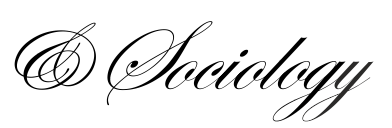

\title{
THE IMPACT OF ASYMMETRIC FISCAL DECENTRALIZATION ON EDUCATION AND HEALTH OUTCOMES: EVIDENCE FROM PAPUA PROVINCE, INDONESIA
}

\author{
Annisa Cahyaningsih, \\ Department of Economics, Faculty \\ of Economics and Business \\ Universitas Gadjah Mada, \\ Indonesia \\ E-mail: \\ annisa.cabyaningsih@mail.ugm.ac.id

\begin{abstract}
Ardyanto Fitrady,
Department of Economics, Faculty

of Economics and Business

Universitas Gadjah Mada,

Indonesia

E-mail:arfie.fitrady@ugm.ac.id
\end{abstract}

Received: August, 2018

1st Revision: January, 2019

Accepted: March, 2019

DOI: $10.14254 / 2071-789 X$.

2019/12-2/3

JEL Classification: $\mathrm{H} 71, \mathrm{H} 72$, $\mathrm{H} 75, \mathrm{H} 77$
ABSTRACT. This study examines the causal effect of asymmetric fiscal decentralization on education and health outcomes in Papua Province, Indonesia, from 1994 to 2016, using the Synthetic Control Method (SCM). The counterfactual series of this study is constructed by using a synthetic control unit deriving data from 21 provinces in Indonesia. It is found that the asymmetric fiscal decentralization which started with the enactment of Law No 21 as of 2001 on Special Autonomy for the Papua Province has negative effects on education and health outcomes in Papua. It is also observed that the outcome gap between the treatment unit and the synthetic control unit also grows over time. Thus, this paper concludes that asymmetric fiscal decentralization is ineffective as evidenced by education and health outcomes in Papua. This paper makes a valuable contribution to the empirical literature on the macroeconomic effects of asymmetric fiscal decentralization. While fiscal decentralization has positive impacts on education and health outcomes in most literature, this paper shows adverse results for the case of Papua Province.

\section{Introduction}

Over the last several decades, asymmetric fiscal decentralization has been implemented in many countries. This phenomenon is mostly intended to achieve more efficient allocations of resources and also better public service provisions. Nevertheless, some empirical evidence indicates that asymmetric fiscal decentralization occurs not only due to economic factors but rather due to political reasons as it is the case in Malaysia (Watts, 2005), Spain (Garcia-Milà \& McGuire, 2007), India (Tillin, 2007; Watts, 1999), and Indonesia (Madubun et al., 2017; Musa'ad, 2011).

For nearly two decades, Indonesia has undertaken the decentralization process following the enactment of the Law No. 22 of 1999 on Local Governments and Law No. 25 of 1999 on Fiscal Balance between the Central and the Local Governments. As a special case, 
Papua is one of the provinces granted the status of special autonomy that is often known as one form of asymmetric decentralization. Under this status, Papua has higher revenue sharings on some strategic sectors, such as oil mining and natural gas mining as compared to other provinces in Indonesia. Moreover, the Central Government grants Papua a special revenue fund intended for education and healthcare provisions amounting to two percent from the national general allocation fund. The asymmetric fiscal arrangement in Papua is expected to improve the living standards of the Papuans, especially in terms of healthcare and education. In fact, education and healthcare outcomes in Papua are far below the other provinces in Indonesia.

There is plenty of evidence on the benefits of fiscal decentralization, for both with and without asymmetric arrangement. In part of public service provisions, fiscal decentralization improves the public-school enrollment rates (Faguet \& Sanchez, 2008; Peña, 2007), widens childhood immunization coverage (Khaleghian, 2003), and reduces infant mortality rates (Cantarero \& Pascual, 2007; Rubio et al., 2010; Samadi et al., 2013). On the other hand, fiscal decentralization generates negative economic implications such as efficiency disadvantages (Rodriguez-Pose \& Gill, 2005) and corruption (Kraemer, 1997). Thus, it is still debatable whether the asymmetric arrangement of decentralization will increase education and healthcare provisions. Not much has been known about the actual effect of asymmetric fiscal decentralization on public service provisions in Indonesia. Therefore, the main objective of this study is to fill this research gap.

This research examines the impact of asymmetric fiscal decentralization on healthcare and education outcomes in Papua Province using the synthetic control method devised by Abadie and Gardeazabal (2003). The analysis rests on two different strategies. First, we construct a "synthetic" control region as a counterfactual of a status quo using a combination of other provinces that do not have asymmetric fiscal decentralization before the implementation of the asymmetric fiscal decentralization in Papua province. Second, we use the enactment of Law No 21 as of 2001 on Special Autonomy for the Papua Province as a natural experiment to estimate the effect of asymmetric fiscal decentralization in Papua Province.

This study is constructed as follows. Section 2 presents the theory on fiscal decentralization, the implementation of asymmetric fiscal decentralization in Indonesia and several other countries along with the analysis of previous research in the field. Section 3 discusses the data and methodologies employed in this paper. Section 4 reports and discusses the results. Section 5 concludes and provides policy recommendations.

\section{Literature review}

\section{Fiscal decentralization}

Fiscal decentralization refers to the delegation of fiscal responsibilities from the central government to the sub-national or local government to create an efficient distribution of public sector provisions (Meehmod et al., 2010). The logic behind this fiscal decentralization theorem is mainly derived from the decentralization theory developed by Tiebout (1956) and the theory of public finance developed by Musgrave (1959). Tiebout (1956) points out that decentralized provisions of public goods allow better accountability and fulfillment of diverse individual preferences. This would happen since accountability is ensured by consumer choice. Under fiscal decentralization, local governments would offer different levels of public goods provisions, and people would respond by moving to a jurisdiction where the public provision level fits their preferences. Musgrave (1959) explains the role of government through budget policy i.e. resource allocation, distribution, and stabilization. The idea of fiscal decentralization stems from the allocation problem in which 
government finds it difficult to identify public needs and make optimal solutions to satisfy them efficiently. This theory was then elaborated by Oates (1972). He argues that as long as public sector provisions are tailored to the preferences of the society by each local authority, the economic efficiency can be achieved. Oates (1999) states further that local government officials tend to have better information about their regional circumstances. Those officials are able to obtain accurate information about their community preferences and cost conditions. Hence, the local policymakers have more knowledge to implement their policies.

Fiscal decentralization differs from one country to another due to differences in history, culture, economic, social, and political systems. Those variations can even arise within the country and may influence the social perspective on autonomy, independence, and fiscal authority (Garcia-Milà \& McGuire, 2007). It is, therefore necessary to have an unusual fiscal decentralization system capable of accommodating those differences while taking the general objective of the country into account (Huda, 2014). Tarlton (1965) introduces two notions of decentralization: symmetric decentralization and asymmetric decentralization. The latter occurs where there is a differentiation in the magnitude of autonomy and division of power among the local governments. This model may arise because of political reasons (to alleviate political tension), or economic reasons (to obtain economic efficiency) (Wehner, 2000). To understand asymmetric decentralization, three dimensions of asymmetric decentralization are considered: (1) political asymmetry, which refers to the capacity or assignment differences among local government units; (2) administrative asymmetry, which is concerned with the differences on how political institutions turn policy decisions into allocative outcomes; and (3) fiscal asymmetry, which related to the differences on revenue and spending pattern and how each of the local units rectifies imbalances (Bird, 2003; Litvack et al., 1998; White, 2011).

Fiscal asymmetry decentralization could be implemented as different fiscal transfers, share of central tax revenues, fiscal responsibility assignments and also fiscal autonomy for different local governments. Although these differences are believed to create economic efficiency, it is still arguable whether the public service provisions will be better off with an asymmetric decentralization system compared to a symmetric decentralization.

There are some examples of asymmetric decentralization successes such as in India, Malaysia, Spain, and Palestine. The use of asymmetric decentralization in two Borneo states, Sabah and Serawak, has enabled Malaysia to accommodate its internal diversities for over four decades (Watts, 2005). Asymmetric decentralization also helped to alleviate some of political tension in three regions of Spain (Garcia-Milà \& McGuire, 2007). On the contrary, some countries experienced different results due to the implementation of asymmetric decentralization. In some cases, the tension between symmetric system supporters and asymmetric system supporters led to the disintegration of the federations.

Spain and India have political backgrounds behind their asymmetric fiscal decentralization. The studies on both countries show that asymmetric fiscal decentralization has generally positive impacts on public service provisions. Decentralization in Spain has positively impacted public provisions in general. Solé-Ollé and Esteller-Moré (2005) states that government-efficiency improvements in Spain raise the percentage of successful students in the last course of secondary education. In the health sector, decentralization has a negative significant association with infant mortality rates and a positive significant association with life expectancy over 1992 to 2003 (Cantarero \& Pascual, 2008). On the other case, strong evidence from India's panel data shows that asymmetric fiscal decentralization in rural villages in India has a negative correlation with infant mortality rates (Asfaw et al., 2007). Fiscal decentralization also corresponds positively to regional economic growth (Zhang \& Zou, 1998), encourage poverty alleviation (Bardhan \& Mookherjee, 2003), and contribute to the reduction of economic disparity among regions (Bagchi, 2003). 
Indonesia, over the past two decades, has undertaken a process of decentralization. Two laws on the subject of local government and fiscal balance were passed in 1999 and initiated the decentralization era in Indonesia. Central government, through Law No. 22 of 1999 on Local Government and Law No. 25 of 1999 on Fiscal Balance between the Central and the Local Government, delegates political authority and fiscal resources to the provinces and municipalities at the subnational level. The reform is expected to enhance public service provisions including health and education services. The Indonesian government has implemented both symmetric and asymmetric decentralization. It implements asymmetric decentralization in certain provinces, i.e. Aceh, Jakarta, Yogyakarta, Papua and Papua Barat. The essential considerations that motivate the application of asymmetric decentralization in those provinces are quite varied. Aceh, Papua and Papua Barat obtain asymmetric decentralization with the aim of reducing the desire of separation. While, historical-cultural dimension could be seen as the dominant determinant in Daerah Istimewa Yogyakarta (Madubun, 2017; Musa'ad, 2011). Administrative decentralization was followed by fiscal decentralization in all regions. Although, each level of government has its own funds, most of the revenue comes from the central government in the form of general allocation fund which is at least twenty six percent of central government domestic revenues (Ranis \& Steward, 1994). The introduction of asymmetric decentralization in Indonesia brings about differences in financing and spending patterns which may improve or worsen the efficiency and effectiveness of the public sector provision as a whole (Bird, 2003).

In recent years, a great deal of work has been done to investigate the impacts of fiscal decentralization on economic growth and public sector provisions. Fiscal decentralization has generally positive impacts on education and health outcomes. Many countries have implemented asymmetric decentralization, but relatively little empirical research has been conducted to compare the impact of symmetric and asymmetric fiscal decentralization.

Faguet \& Sanchez (2008) employ two-stage least square panel estimation to evaluate the impact of decentralization in terms of public education outcome in Colombia during the period of 1994 to 2001. They find that fiscal decentralization enhances the public-school enrollment rates. Similar results are also found in other studies. Peña (2007) studies the decentralization effect on the Survival Rate i.e. the ratio of students in last course of ESO (compulsory secondary education) who entered Bachillerato (upper secondary education) in Spain. The results show that the decentralization process has a positive impact on education aftereffect, measured as the Survival Rates. It is believed that the escalation in Survival Rate from 1980 to 2003 has been mainly stimulated by an improvement of government efficiency. Salinas and Solé-Ollé (2018) also estimates the effect of decentralization reform in Spain. They point out that decentralization reform reduced the dropout rate in secondary education by around 1.5 percentage point on average. Barankay and Lockwood (2007) confirm in 26 Swiss cantons that there is a robust positive association between fiscal decentralization and public good provision in the case of education.

In the case of the health sector, there are studies that employ various health outcome variables in order to evaluate the effect of fiscal decentralization such as health expenditures (Rubio, 2010; Schwartz et al., 2002; Uchimura, 2012), childhood immunization coverage (Khaleghian, 2003) and infant mortality rates (Cantarero \& Pascual, 2008; Jimenez-Rubio, 2010; Samadi et al., 2013). Schwartz et al. (2002) estimates the impact of fiscal devolution on per capita health expenditures. The results suggest that fiscal devolution stimulated the rise of per capita health expenditure in the Philippines from 1995 to 1998. In addition, Rubio (2010) states that fiscal decentralization of health services in Canada has a positive and substantial influence on the effectiveness of public policy in enhancing a population's health over the period studied. The horizontal fiscal balance among local governments played an important role for better health attainment (Uchimura, 2012). Sanogo (2018), using local government 
revenue dataset from 2001 to 2011 for 115 municipalities, states that fiscal decentralization positively affects the access to public services such as health services and education services in Côte d'Ivoire municipalities.

Cantarero and Pascual (2008) tests empirically whether fiscal decentralization leads to improvement in health of population in Spain measured by infant mortality rates. They find that fiscal decentralization indicators along with per capita income and general practitioners are negatively related to infant mortality. This argument is then supported by evidence in other regions. Rubio (2010) and Samadi et al. (2013) also find that fiscal decentralization has negative impacts on infant mortality rates in 19 OECD countries and Iran, respectively. Although infant mortality is a better indicator than other health indicators such as immunization coverage and life expectancy, it does not completely reflect the underlying magnitude of health in a society (Rubio, 2010). Therefore, many studies use a combination of health variables and other social variables such as human development index.

The discussion above shows that fiscal decentralization may generate negative as well as positive economic implications. Rodriguez-Pose and Gill (2005) classifies economic burdens that may occur due to fiscal decentralization into three categories, i.e. efficiency disadvantages, equity related drawbacks, and institutional burdens. Prud'homme (1995) states that low economic opportunities, poor infrastructure, unskilled labor and externalities are the reasons of poverty in low income regions, not necessarily due to fiscal decentralization. Hence, the impact of fiscal decentralization in poor regions is still debatable. Other than that, there is another problematic issue that stems from fiscal decentralization, i.e. corruption. Kraemer (1997) argues that corruption may actually worsen with the fiscal decentralization. Based on the literature review it is quite obvious that there are still knowledge gaps to be filled as far as the links between asymmetric fiscal decentralization and public service provisions such as education and health are concerned. The existing literature on the relationship between asymmetric fiscal decentralization and human development aspects, especially education and health sectors, does not provide an output comparison between asymmetric and symmetric fiscal decentralization. In general, fiscal decentralization has positive impacts on education and health outcomes. However, the previous literature employed partial variables, providing incomprehensive results. This research uses a composite variable on the education sector, a combination of net enrollment rates of primary and senior secondary education. This research utilizes the synthetic control method (SCM) to overcome the research subject assortment problem that is usually found in the traditional comparative-case-study method (Difference-in-Difference, DiD). The traditional method used by most literature leaves the choice of control units to the researcher - this action prompting questions about the arbitrariness of research subject assortment. Moreover, the method used in this research (SCM) also allows the effect of unobserved confounding characteristics to vary over time. Thus, we can expect to have more accurate results.

\section{Fiscal Decentralization in Papua Province}

The enactment of Law No 21 of 2001 on Special Autonomy for the Papua Province inaugurate asymmetric decentralization in Papua. Article 1 of the Law No 21 of 2001 states "Special Autonomy is a special authority acknowledged and granted to the Papua Province to regulate and manage the interests of the local people based on the aspiration and fundamental rights of the people of Papua". In order to carry out its duties, local governments have several revenue streams such as the local-own revenues, the balancing funds, the revenue of the province in the context of the special autonomy, and other revenues. Revenue sharing between central government and the local government is a consequence of the duty sharing. The principle of revenue sharing policy is regulated in Law No 33 of 2004 on Fiscal Balance between the Central and the Local Governments. Based on that regulation, each source of 
funding has different purpose and function. Local-own revenues aim to finance local autonomy as a manifestation of decentralization, while balancing funds from the central government aims at closing the fiscal gap between the central and the local governments and among the local governments.

Revenue-sharing fund (Dana Bagi Hasil, DBH) received by the provincial government varies in term of percentages. Both Papua and other provinces that have symmetric fiscal decentralization share the same percentage in the revenue-sharing proceeds derived from taxes. Property tax (Pajak Bumi dan Bangunan, PBB), land and building title transfer duty (Bea Perolehan Hak atas Tanah dan Bangunan, BPHTB), and income tax (Pajak Penghasilan, $\mathrm{PPh}$ ) have percentages of 90 percent, 80 percent, and 20 percent respectively. The proportion of revenue sharing funds derived from natural resources also shows similarities in some sectors (forestry, fisheries and general mining). However, shares for oil mining and natural gas mining sectors are higher for Papua province than shares for other provinces with symmetrical decentralization. Papua's share in the oil mining sector is 70 percent which is almost five times greater than the other provinces, while its share in natural gas mining is 40 percent higher than the remaining provinces.

The central government attempts to improve standards of public capital for services such as education and health in Papua Province. In the context of the implementation of special autonomy, Papua province earned special revenues intended for education and health provision which amounted to two percent from national general allocation fund. Furthermore, the government regulates the use of revenue sharing funds derived from oil and natural gas mining whereby at least 30 percent and 15 percent of revenues are allocated to education and health provision, respectively. On the other hand, there is an additional fund for infrastructure development to stimulate economic growth. Those funds are expected to alleviate the economic, education, and health problems and also reduce the local disparities between Papua and other provinces.

\section{Methodological approach}

\section{Data}

The data used for the study is an annual province-level panel dataset covering the period 1994 to 2016. The asymmetric fiscal decentralization in Papua Province was passed in 2001, which gives a pre-asymmetric decentralization sample running from 1994 to 2000 . The post-intervention period runs for 16 years from 2001 to 2016. The outcome variable of interest is annual education and health indicators at province level. The outcome data was obtained from the Statistical Yearbook of Indonesia and Indonesia Health Profile. This study set the period of the observation from 1994 to 2016 due to the data availability of predictor variables (birth attended by skilled health personnel).

The predictor employed for the study based on a regression model is designed by Mehmood et al. (2010) and Samadi et al. (2013). Mehmood et al. (2010) constructs an empirical model to estimate the relationship between public service provisions outcome and asymmetric fiscal decentralization using the ratio of local-own revenue to total revenue and the ratio of expenditure over total expenditure. Samadi et al. (2013) estimates the effect of fiscal decentralization on health output using the gross domestic product. The predictors of education and health outcomes used for this study are: the ratio of local-own revenue to total revenue, the log of education and health expenditures, the log of per capita gross regional domestic product, and the lags of the education and health outcomes. These variables are averaged over the 1994-2000 period and augmented by adding three years of lags of education or health outcomes (1994, 1998, and 2000). The predictors used in this section come from the Ministry of Finance and Statistical Yearbook of Indonesia. The variables in 
this study are selected from the available indicators using the sensitivity test where the selection depends on the least root mean squared prediction error (RMSPE) in the model. This test is utilized to assess the potential pitfall by evaluating the effect of the choice of predictors and outcome lags used as the predictors. The least possible RMSPE indicates the best empirical model. In order to check the robustness of the result, Dupont IV et al. (2015) suggests to use the model with RMSPE less than ten percent.

The combination of net enrollment rates of primary education and net enrollment rates of secondary education has the minimum RMPSE on the education sector, while the birth attended by skilled health personnel has the least RMPSE on the health sector. In the case of Papua Province, both education and health outcomes grow much more slowly throughout the observation periods as can be seen in Figure 1. Education and health outcomes have an upward trend with an average growth rate of 0.014 and 1.84 percent per year respectively. A question remains whether these changes are substantially influenced by the policy intervention or other factors.
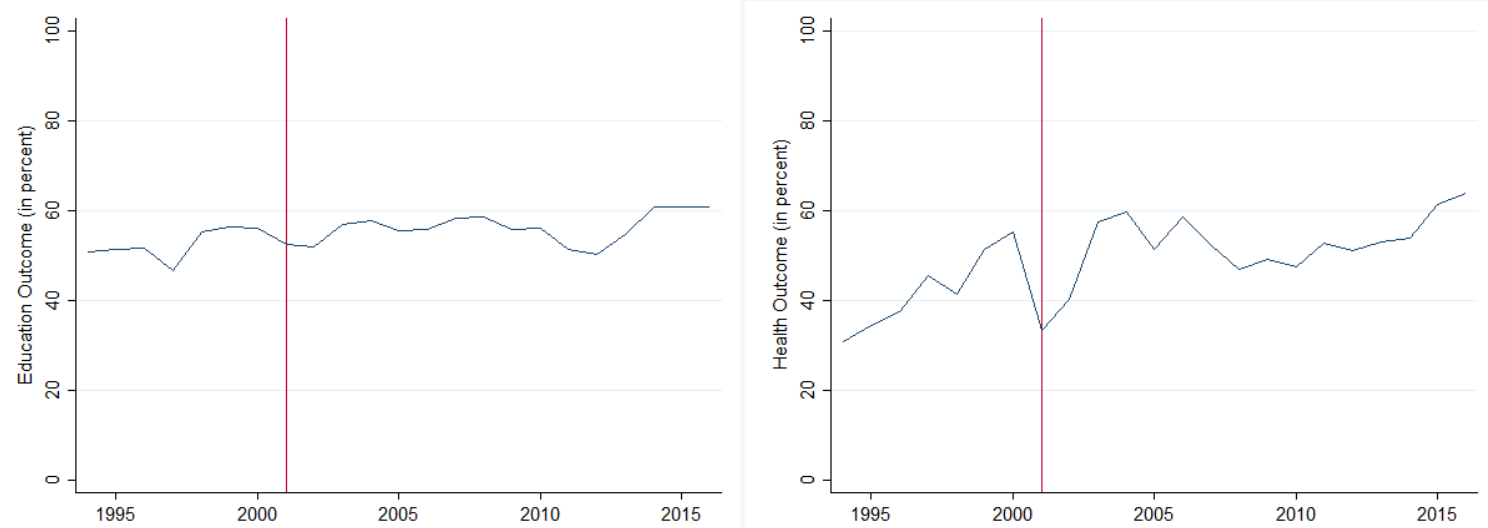

Figure 1. Education and health outcomes in Papua Province period 1994-2016 (statistical yearbook of Indonesia and Indonesia health profile, statistics Indonesia, multiple years)

The choice of outcome lags plays an important role in the model of fits. McCleland and Gault (2017) states that the choice of outcome lags influences the choice of donor pool selection so it affects the synthetic control model. Outcome lags also eliminate the problem of omitting important predictors' effects as it takes into consideration the consequences of any predictor variable whether or not they are gathered by the study. Nevertheless, including all outcome lags for all pretreatment years will render the other predictor variables (Kaul et al., 2016). Hence, the best combination of outcome lags is needed in order to form the fittest synthetic control model.

Table 1. Sensitivity Test Result for Outcome Lags

\begin{tabular}{ccc}
\hline \multirow{2}{*}{ Predictor with Outcome Lags } & Rducation & Health \\
\cline { 2 - 3 } & 1.317747 & 1.418535 \\
1994 & 1.485455 & 1.416406 \\
1995 & 1.485455 & 1.416406 \\
1996 & 1.438239 & 3.113408 \\
1997 & 1.437664 & 1.816199 \\
1998 & 2.330295 & 1.874864 \\
1999 & 1.5073604 & 1.980679 \\
1000 & 1.377043 & 1.617204 \\
$1995 ; 1998$ & 1.317746 & 1.005346 \\
$1995 ; 1998 ; 2000$ & 1.317746 & 0.91725 \\
\hline
\end{tabular}

Source: Authors' calculations. 
This study compares the RMPSE of the model with a combination of one lag to all lags (1994 to 2000). The minimum RMSPE will generate the best estimation for the synthetic control.

Based on Table 1, the RMPSE varies noticeably with the choice of the outcome lags. To determine important lag among all pre-intervention years, this study examines the year lag one at a time. Year 1994 is an essential year for education, whereas 1995 and 1996 are important years in the health sector since they have the least RMPSE for an individual test. The combination of three years (1994, 1998, and 2000) offers the least RMPSE for the education and health sector, even though year 1995 is important for the health sector. This research uses the same year combination for both sectors to create the same circumstance.

\section{Provinces Selection}

The donor pool for the synthetic control analysis is composed of provinces that do not have asymmetric fiscal decentralization. McClelland and Gault (2017) outlines the necessary conditions to become the donor pool of the synthetic control unit. First, the provinces should not have asimilar or larger size of intervention as the treated province. Second, the data must be available for several periods prior to the policy intervention for the treated province and the pool of potential donor provinces. Third, provinces in the donor pool should have predictor values that are close to the values of the treated province in the pre-intervention period.

Indonesia has 34 provinces, where five of them have special status. To fulfill the first necessary condition, four provinces with special status (Aceh, DKI Jakarta, Daerah Istimewa Yogyakarta, and Papua Barat) need to be eliminated from the potential donor pool. Afterwards, the remaining 29 provinces are reselected based on data availability during the period of the study. This process fulfills the second necessary condition and leave 21 provinces served as donor pool: Sumatera Utara, Sumatera Barat, Riau, Jambi, Bengkulu, Lampung, Jawa Barat, Jawa Tengah, Jawa Timur, Bali, Nusa Tenggara Barat, Nusa Tenggara Timur, Kalimantan Barat, Kalimantan Tengah, Kalimantan Selatan, Kalimantan Timur, Sulawesi Utara, Sulawesi Tengah, Sulawesi Tenggara, Sulawesi Selatan, and Maluku. The third necessary condition will be explored in the next section.

\section{Methodology}

To evaluate the impacts of asymmetric decentralization on education and health, a comparative case study is needed to compare the outcome of a unit affected by the policy intervention to the outcome for one or more unaffected unit(s). The unaffected units are observed as the proxy for the treated group in the absence of policy intervention. However, the traditional comparative case study methods leave the choice of control units to the researcher, prompting questions about the arbitrariness of control unit assortment and the magnitude to which control units can plausibly reproduce counterfactual outcome of the treated unit. The synthetic control method (SCM) is advocated by Abadie and Gardeazabal (2003) to overcome the control unit shortcomings. Based on the explanation above, SCM is the most suitable method to evaluate the causal effect of asymmetrical fiscal decentralization on education and health in Papua Province.

The synthetic control method (SCM) provides data-driven procedures to construct a suitable control group from a pool of potential control units. It generalizes the difference-indifferences (fixed-effects) model by enabling the effect of unobserved confounding characteristics to vary over time. Abadie and Gardeazabal (2003) defines a synthetic control unit as a weighted average of available control units (donor pool) that estimates the most relevant features of the treated unit prior to the treatment. This approach presents the relative contribution of each available control unit and the degree of correspondence prior to treatment between the treated unit and its synthetic counterpart so that the treated unit outcome of 
pretreatment period can match the outcome of the donor pool in the same period. The postintervention outcomes for the synthetic control units are then used to approximate the outcome that would have been observed for the treated unit in the absence of policy intervention. The weight of control units can be limited to be positive and sum to one in order to protect the estimation against extrapolation outside the framework of the treatment unit data (Abadie et al., 2011).

\section{Model}

Let $Y_{i t}^{I}$ be the outcome variable (education or health outcome) that shall be evaluated based on the asymmetric fiscal decentralization's impact for province $i$, (with $i=1$ for Papua Province and $i>1$ for the donor pool provinces) and time $t$ (for time periods $t=$ $1, \ldots T_{0}, \ldots, T$; where $T_{0}$ is the time of policy intervention, so that unit $i$ is exposed to the intervention in periods $T_{0}$ to $T$ ). Let $Y_{i t}^{N}$ be the outcome variable in the absence of asymmetric fiscal decentralization, where $I$ denotes policy intervention and $N$ denotes the absence of policy intervention. The model requires the assumption that the policy intervention has no effect on the outcome variable prior to the implementation period.

The observed outcome is defined by

$$
Y_{i t}=Y_{i t}^{N}+\alpha_{i t} D_{i t}
$$

where $D_{i t}$ is a dummy variable that is equal to one if unit $i$ is exposed to the policy intervention at time $t$, and is equal to zero otherwise. $\alpha_{i t}$ is the effect of policy intervention for unit $i$ at time $t$. Since there is only one province that is exposed to the asymmetric fiscal decentralization and only after period $T_{0}$, we have

$$
\alpha_{1 t}=Y_{1 t}^{I}-Y_{1 t}^{N}=Y_{1 t}-Y_{1 t}^{N}
$$

Consider that $Y_{1 t}$ is observed. Therefore, to estimate $\alpha_{1 t}$ we need to estimate $Y_{1 t}^{N}$. Following Abadie et al. (2010) $Y_{1 t}^{N}$ is defined as follows.

$$
Y_{i t}^{N}=\delta_{t}+\theta_{t} Z_{j}+\lambda_{t} \mu_{j}+\varepsilon_{j t}
$$

where $\delta_{t}$ is an unknown time factor, $\theta_{t}$ is a vector of unknown parameters, $Z_{j}$ is a vector of observed covariates unaffected by policy intervention, $\lambda_{t}$ is a vector of unknown factor, $\mu_{j}$ is a vector of unknown factor loadings. We are assuming the error $\varepsilon_{j t}$ is independent across units and time with zero mean. As stated in equation 2, consider the first unit be the treated unit, the effect of policy intervention is estimated by approximating the unknown $Y_{1 t}^{N}$ with the weighted average of the donor pool:

$$
\hat{\alpha}_{1 t}=Y_{1 t}-\sum_{j \geq 2} w_{j} Y_{j t}
$$

where $w$ is the weight of control units and $j$ (for $j=2, \ldots, j+1$ ) is the vector of weights. The vector of weights starts from two since the treated unit mark as number one.

Despite the advantages of this method we have discussed under the methodology section, this method has some limitations. First, only the region being studied should receive the treatment. Thus, we cannot have spillovers among regions. The violation of this assumption can lead to an unsuitable synthetic control region. Second, even though synthetic control method allows for valid inferences regardless of the number of the available donor 
pool and the number of the available pre-intervention periods, a small number of donor pool or a small number of time periods will generate low-quality results (Abadie et al. 2010).

\section{Conducting research and results}

We begin by discussing the predictor means that highlights an important feature of synthetic control estimators. The synthetic control method forces the researcher to demonstrate the affinity between the treated unit and its synthetic counterpart which is the weighted average of provinces.

Table 2. Predictor means

\begin{tabular}{llcc}
\hline \multicolumn{1}{c}{ Variables } & \multicolumn{2}{c}{ Papua Province } & $\begin{array}{c}\text { Average of } \\
\text { control provinces }\end{array}$ \\
\hline RLOR (education) & Treated & Synthetic & 36.2001 \\
RLOR (health) & 7.94429 & 14.25661 & 36.2001 \\
Log education expenditure & 7.94429 & 17.36498 & 24.51676 \\
Log health expenditure & 22.89422 & 21.87245 & 24.66516 \\
Log RGDP per capita (education) & 22.96557 & 21.50483 & 15.6506 \\
Log RGDP per capita (health) & 16.15244 & 14.60407 & 15.6506 \\
Education outcome 1994 & 16.15244 & 14.85662 & 59.99978 \\
Education outcome 1998 & 50.75037 & 52.5041 & 62.93614 \\
Education outcome 2000 & 55.395 & 55.54329 & 64.42872 \\
Health outcome 1994 & 56.065 & 55.67301 & 32.75692 \\
Health outcome 1998 & 30.75466 & 30.74636 & 37.89168 \\
Health outcome 2000 & 41.40728 & 42.869865 & 42.91876 \\
\hline
\end{tabular}

Note: All variables except lagged education outcome and health outcome averaged for the 1994-2000 period. Source: Authors' calculations.

As shown in Table 2, education expenditure, health expenditure, and gross regional domestic product (GRDP) of donor pool have values that are close to the values of the treated province in the pre-intervention period. This fulfills the third necessary condition we have discussed above. Although Papua's ratio of local own revenue (RLOR) is lower than the average of donor pool's RLOR, this study uses RLOR as fiscal decentralization indicator since Papua's revenue from balancing funds is relatively larger than other provinces (it is one of Papua's unique features).

Table 3. Province weights in the synthetic Papua

\begin{tabular}{lcclcc}
\hline \multicolumn{1}{c}{ Provinces } & \multicolumn{2}{c}{ Weight } & \multicolumn{2}{c}{ Provinces } & \multicolumn{2}{c}{ Weight } \\
& Education & Health & & 0.842 & 0 \\
\hline Sumatera Utara & 0 & 0 & Nusa Tenggara Timur & 0 & 0 \\
Sumatera Barat & 0 & 0 & Kalimantan Barat & 0 & 0 \\
Riau & 0 & 0 & Kalimantan Tengah & 0 & 0 \\
Jambi & 0 & 0 & Kalimantan Selatan & 0 & 0 \\
Bengkulu & 0 & 0.385 & Kalimantan Timur & 0 & 0 \\
Lampung & 0 & 0 & Sulawesi Utara & 0.158 & 0 \\
Jawa Barat & 0 & 0 & Sulawesi Tengah & 0 & 0 \\
Jawa Tengah & 0 & 0 & Sulawesi Selatan & 0 & 0 \\
Jawa Timur & 0 & 0 & Sulawesi Tenggara & 0 & 0.256 \\
Bali & 0 & 0 & Maluku & & 0 \\
Nusa Tenggara Barat & 0 & 0.359 & & & \\
\hline
\end{tabular}

Source: Authors' calculations. 
Table 3 displays the weight of each control province in the synthetic Papua province. The weight reported on Table 3 indicates that the education outcome in Papua prior to the asymmetric fiscal decentralization enactment in 2001 is best reproduced by a combination of Nusa Tenggara Timur (84.2\%) and Sulawesi Tengah (15.8\%), while the health outcome is best reproduced by a combination of Bengkulu (38.5\%), Nusa Tenggara Barat (35.9\%), and Maluku $(25.6 \%)$. All other provinces in the donor pool receive a weight of zero.

\section{Findings}

Figure 2 shows the evolution of education and health outcomes in Papua Province and its synthetic counterparts between 1994 and 2016. The evolution of the outcome in the actual province and its synthetic controls match closely prior to the enactment of asymmetric fiscal decentralization. It proves that synthetic controls can closely track the movement of the actual data over the long pre-intervention period.
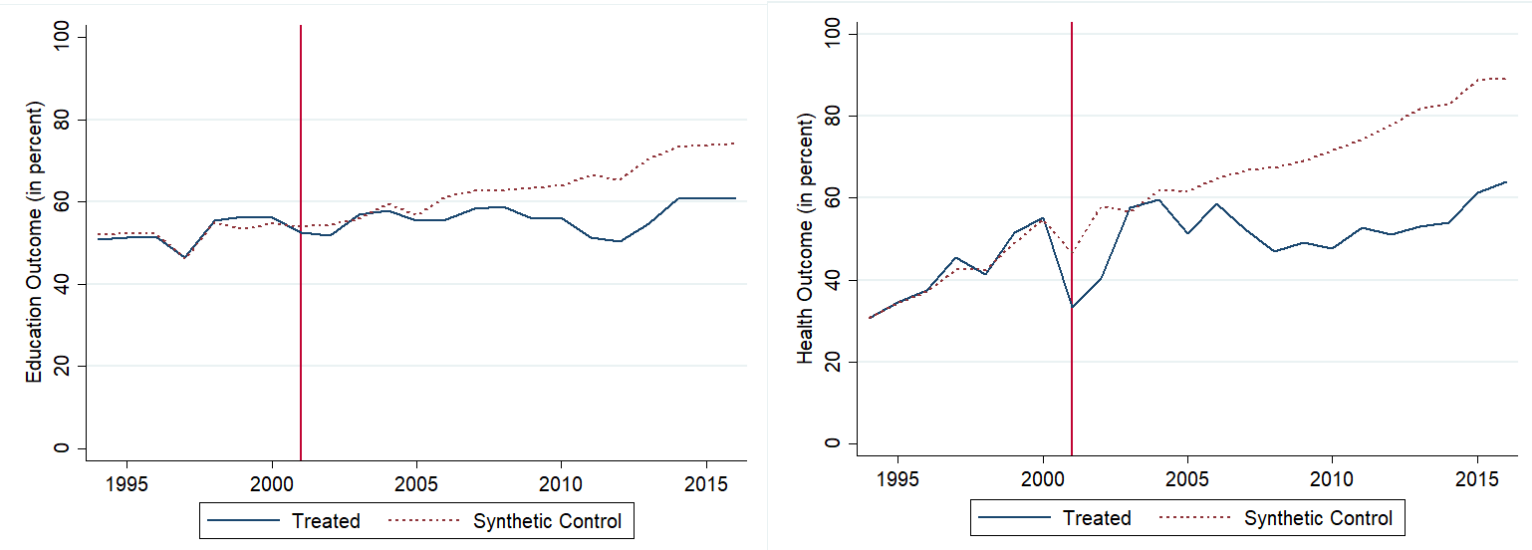

Figure 2. Trends in education and health outcomes: Papua vs. synthetic control

The trajectory of Papua Province and its synthetic control start to diverge after the asymmetric fiscal decentralization is introduced in both education and health sectors. The synthetic controls in both sectors are consistently above the actual outcome. While the asymmetric fiscal decentralization supposed to improve the education and health outcome, the result provides empirical support that the asymmetric fiscal decentralization has a negative effect on education and health outcome in Papua.
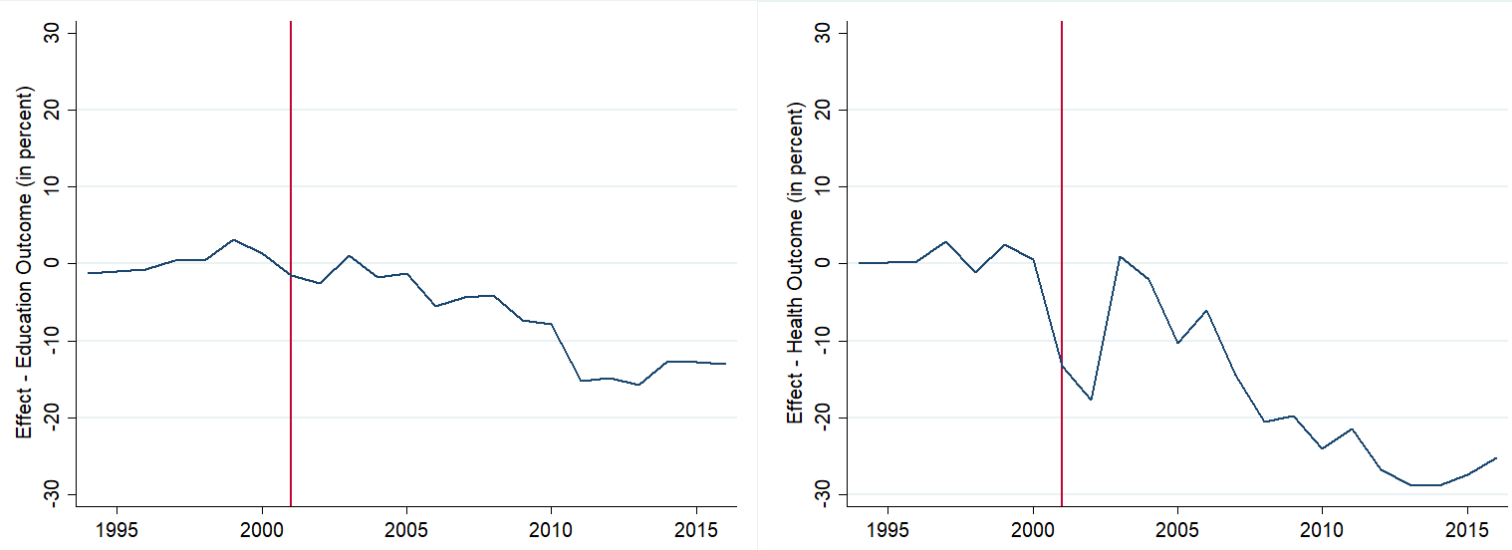

Figure 3. Education and health outcome gaps: Papua vs. synthetic control 
The causal effects of the asymmetric fiscal decentralization on education and health are plotted over time in Figure 3. It is calculated as the gap between Papua and its synthetic counterpart in the post-intervention period. Figure 3 shows that asymmetric fiscal decentralization has a negative effect on the education and health outcomes of Papua Province. Another interesting result is the outcome gaps grew over time especially after year 2003, despite the fact that balancing funds continue to increase. There are several potential causes that can lead to failure of fiscal decentralization. The World Bank (2005) points out that fiscal decentralization has to be accompanied by competent human resources and managerial capacity. In fact, the low education attainment in Papua leads to a small number of qualified human resources. It is exacerbated by the poor health profile which reduces productivity. Another concern is the possibility that decentralization might be accompanied by more corruption (Prud'homme, 1995). Iry (2009) claims that Papua's special revenue mostly is beneficial for local elites. Thus, Papua's additional fund is ineffective to improve public service provisions. The World Bank (2005) also warns that unbridled spending by local elites drives inefficient service provisions since revenue sharing funds are determined by agreement and not tailored to the expenditure target.

\section{Placebo Test}

Following Abadie and Gardeazabal (2003), this study constructs a test where asymmetric fiscal decentralization implementation is reassigned to provinces other than Papua Province to assess the asymmetric fiscal decentralization effect on education and health. Placebo test answers the question of how education and health would change, assuming that control provinces (donor pool) behave as if they have asymmetric fiscal decentralization. If the placebo studies create gaps of a degree close to the one estimated for Papua, then the interpretation of the analysis does not provide significant evidence of a negative effect of asymmetric fiscal decentralization on education and health outcomes in Papua. On the other hand, if the placebo test shows that the gap estimated for Papua is unusually large relative to the provinces that do not have asymmetric fiscal decentralization, then the interpretation of this study provides significant evidence of a negative effect of asymmetric fiscal decentralization on education and health outcomes in Papua.
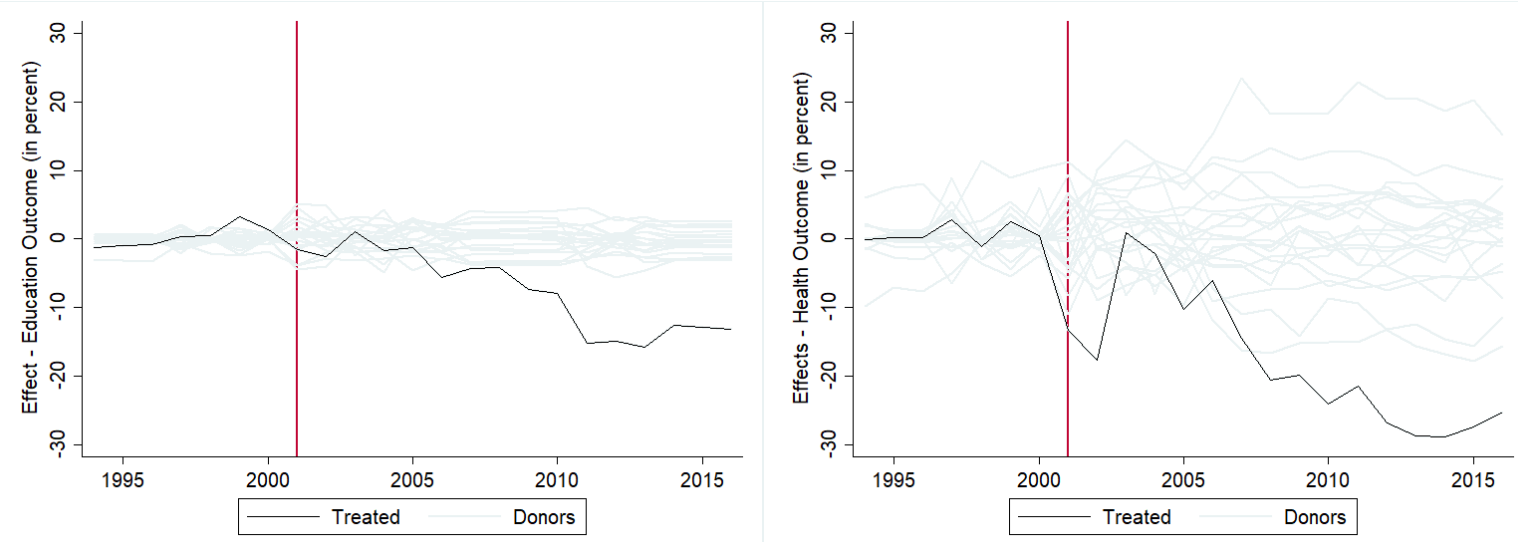

Figure 4. Placebo test for education and health outcomes

Figure 4 displays the results for the placebo test. The gray lines represent the gap associated with each of the 21 runs of the test. It shows the difference in education and health outcome between each province in the donor pool and its respective synthetic version. The black line denotes the gap estimated for Papua Province. As the figure makes visible, the estimated gap for Papua during the 2001-2016 period is unusually large relative to the distribution of gaps for the provinces in the donor pool for both education and health. 
Therefore, we can conclude that there is significant evidence of a negative effect of asymmetric fiscal decentralization on education and health in Papua.

This result contradicts most previous studies but is in line with Prud'homme's finding (1995). The negative effect of asymmetric fiscal decentralization may arise from the characteristics of low-income regions such as unskilled labor and poor infrastructure. As discussed in the literature review, Papua has experienced a prolonged confrontation obstructing its economic and political development. Its lack of capabilities results in a significant gap between Papua and other regions.

\section{Conclusion}

This study examines the causal effect of asymmetric fiscal decentralization on education and health sectors in Papua Province using the synthetic control method. The method allows researchers to compare the actual post-intervention outcome of treatment unit with a counterfactual series constructed by synthetic control unit deriving from donor pool and utilizes a placebo test in order to test the significance of the results.

The results show that asymmetric fiscal decentralization which is marked by the enactment of Law No 21 of 2001 on Special Autonomy for the Papua Province has a negative effect on education and health outcomes in Papua. Both education and health outcome gaps between the treatment unit and the synthetic control unit grow over time. The significance of the result is also confirmed by the Placebo test that provides evidence of a significant negative effect of asymmetric fiscal decentralization on education and health outcomes in Papua. Thus, we can conclude that asymmetric fiscal decentralization is unable to improve education and health provisions in Papua.

This study makes a valuable contribution to the empirical literature on the macroeconomic effects of asymmetric fiscal decentralization on education and health. While fiscal decentralization has positive impacts on education and health outcomes in the most previous literature, this study shows adverse results for the case of Papua. The lack of clarity in the allocation and distribution of functions between the center and the local governments can lead to an overlap of responsibilities. It creates difficulties to assign precise expenditure responsibilities. This problem leads to unbridle spending of both central and local government and also increases the chance of corruption as pointed out by Nasution (2016). Meanwhile, a low level of political decentralization can erode the effectiveness of fiscal decentralization in improving public service provisions (Asfaw et al., 2007). So, it is important to establish specific regulations governing the function distribution between central and local government related to education and health provisions. Furthermore, the regulation implementation has to be followed by the improvement of government officials' capabilities. Nasution (2016) states that every local government has different capabilities to deliver services in education, health, and other areas. Hence the central government should supervise the local government to improve their capabilities through training programs focused on and built around specific subject area needs of decentralization (Alm et al., 2001). A combination of policies and effective law implementation are crucially needed to successfully combat possible problems such as incompetent human resources, corruption, and uncontrolled spending.

The result highlights whether asymmetric fiscal decentralization affects the education and health sectors in Papua. This study can merely approximate the factors of asymmetric fiscal decentralization default based on existing literature. Hence, a study on the underlying causes of asymmetric fiscal decentralization failure in Papua should be emphasized in future research. 


\section{References}

Abadie, A., Diamond, A., \& Hainmueller, J. (2010). Synthetic control methods for comparative case studies: Estimating the effect of California's tobacco control program. Journal of the American statistical Association, 105(490), 493-505.

Abadie, A., Diamond, A., \& Hainmueller, J. (2011). Synth: An r package for synthetic control methods in comparative case studies. Journal of Statistical Software, 42(13), 1-17.

Abadie, A., \& Gardeazabal, J. (2003). The economic costs of conflict: A case study of the Basque Country. American economic review, 93(1), 113-132.

Alm, J., Aten, R. H., \& Bahl, R. (2001). Can Indonesia decentralise successfully? Plans, problems and prospects. Bulletin of Indonesian Economic Studies, 37(1), 83-102.

Asfaw, A., Frohberg, K., James, K. S., \& Jütting, J. (2007). Fiscal decentralization and infant mortality: empirical evidence from rural India. The Journal of Developing Areas, 17-35.

Bagchi, A. (2003). Rethinking federalism: changing power relations between the center and the states. Publius: The Journal of Federalism, 33(4), 21-42.

Barankay, I., \& Lockwood, B. (2007). Decentralization and the productive efficiency of government: Evidence from Swiss cantons. Journal of public economics, 91(5-6), $1197-$ 1218.

Bardhan, P., \& Mookherjee, D. (2003). Poverty alleviation effort of West Bengal panchayats. Economic and Political Weekly, 39(9), 965-974.

Bird, R. M. (2003). Asymmetric Fiscal Decentralization: Glue or Solvent? (No. paper0309). International Center for Public Policy, Andrew Young School of Policy Studies, Georgia State University.

Cantarero, D., \& Pascual, M. (2008). Analysing the impact of fiscal decentralization on health outcomes: empirical evidence from Spain. Applied Economics Letters, 15(2), 109-111.

Dupont IV, W., Noy, I., Okuyama, Y., \& Sawada, Y. (2015). The Long-Run Socio-Economic Consequences of a Large Disaster: The 1995 Earthquake in Kobe. RIETI Discussion Paper Series, 15-E-035, 1-22.

Faguet, J.P., \& Sánchez, F. (2014). Decentralization and access to social services in Colombia. Public Choice, 160(1-2), 227-249.

Faguet, J. P., \& Sanchez, F. (2008). Decentralization's effects on educational outcomes in Bolivia and Colombia. World Development, 36(7), 1294-1316.

Garcia-Milà, T., \& McGuire, T. (2007). Fiscal decentralization in Spain: an asymmetric transition to democracy. Fiscal Fragmentation in Decentralized Countries, 208-223.

Huda, Ni'matul. (2014). Desentralisasi Asimetris dalam NKRI: Kajian terhadap Daerah Istimewa, Daerah Khusus dan Otonomi Khusus. Bandung: Nusa Media.

da Iry, A. G. (2009). Dari papua meneropong Indonesia. Jakarta: PT. Gramedia Widiasarana Indonesia.

Rubio, D.J., Prieto, D.C., \& Sáez, M.P. (2011). Is fiscal decentralization good for your health? Evidence from a panel of OECD countries. In XVIII Encuentro de economía pública, 63.

Kaul, A., Klößner, S., Pfeifer, G., \& Schieler, M. (2015). Synthetic control methods: Never use all pre-intervention outcomes together with covariates.

Khaleghian, P. (2003). Decentralization and public services: the case of immunization. The World Bank.

Kraemer, M. (1997). Intergovernmental transfers and political representation: empirical evidence from Argentina, Brazil and Mexico (No. 345). Working Paper, Inter-American Development Bank, Office of the Chief Economist.

Seymour, R., \& Turner, S. (2002). Otonomi daerah: Indonesia's decentralisation experiment. New Zealand Journal of Asian Studies, 4, 33-51. 
Law No. 25 of 1999 on Fiscal Balance between the Central and the Local Government. Republic of Indonesia. 19 May 1999.

Law No. 21 of 2001 on Special Autonomy for the Papua Province. Republic of Indonesia. 21 November 2001.

Law No. 32 of 2004 on Local Autonomy. Republic of Indonesia. 15 October 2004.

Law No. 33 of 2004 on Fiscal Balance between the Central and the Local Government. Republic of Indonesia. 15 October 2004.

Letelier S, L., \& Ormeño C, H. (2018). Education and fiscal decentralization. The case of municipal education in Chile. Environment and Planning C: Politics and Space, 36(8), 1499-1521.

Litvack, J., Ahmad, J., \& Bird, R. (1998). Rethinking decentralization in developing countries. The World Bank.

Madubun, J., Akib, H., \& Jasruddin. (2017). The Prototype Model of Asymmetric Decentralization in Providing Public Services to the Island Areas. Mediterranean Journal of Social Sciences, 8(2), 209-18.

McCleland, R \& Gault, S. (2017). The Synthetic Control Method as a Tool to Understand State Policy. Washington, DC: Urban Institute.

Mehmood, R., Sadiq, S., \& Khalid, M. (2010). Impact of Fiscal Decentralisation on Human Development: A Case Study of Pakistan [with Comments]. The Pakistan Development Review, 513-530.

Ministry of Finance Republic of Indonesia. (2018). Local Financial Data. Accessed on 23 March 2018. http://www.djpk.kemenkeu.go.id

Musa'ad, M. A. (2016). Kontekstualisasi Pelaksanaan Otonomi Khusus di Provinsi Papua: Perspektif Struktur dan Kewenangan Pemerintahan. Kajian, 16(2), 357-385.

Musgrave, A.R. (1959). The Theory of Public Finance. New York. Toronto and London: McGraw-Hill.

Nasution, A. (2017). The government decentralization program in Indonesia. In Central and Local Government Relations in Asia. Edward Elgar Publishing.

Oates, W.E. (1972). Fiscal Federalism. New York: Harcourt Brace Jovanovich.

Oates, W.E. (1999). An Essay of Fiscal Federalism. Journal of Economic Literature, 37(3), $1120-1149$

Peña, P.S. (2007). Evaluation of the Effects of Decentralization on Educational Outcomes in Spain. XIV Encuentro de Economia Publica, Universidad de Santander, Spain.

Prud'homme, R. (1995). The dangers of decentralization. World Bank Research Observer, 10, 201-220.

Ranis, G. \& Steward, F. (1994). Decentralisation in Indonesia. Bulletin of Indonesian Economic Studies, 30(3), 41-72.

Rodríguez-Pose, A. \& Gill, N. (2005). On the Economic Dividend of Devolution. Regional Studies, 39(4), 405-420.

Salinas, P. \& Solé-Ollé, A. (2018). Partial Fiscal Decentralization Reforms and Educational Outcomes: A Difference-in-differences Analysis for Spain. Journal of Urban Economics, 107(9), 31-46.

Samadi, A. H., et al. (2013). The Effect of Fiscal Decentralization on Under-five Mortality in Iran: A Panel Data Analysis. Health Policy and Management, 1(4), 301-306.

Sanogo, Tiangboho. (2019). Does Fiscal Decentralization Enhance Citizens' Access to Public Services and Reduce Poverty? Evidence from Côte d'Ivoire Municipalities in a Conflict Setting. World Development, 113(1), 204-221.

Schwartz, J., Guilkey, D., \& Racelis, R. (2002). Decentralization, allocative efficiency and health service outcomes in the Philippines. In Measure Evaluation. Chapel Hill, North Carolina: Carolina Population Center University of North Carolina. 
Solé-Ollé, A. \& Esteller-Moré, A. (2005). Decentralization Provision of Public Inputs, Government Responsiveness to Local Needs, and Regional Growth: Evidence from Spain. Institut d'Economia de Barcelona Working Paper. Barcelona: Institut d'Economia de Barcelona.

Tanzi, V. (2002). Pitfalls on the Road to Fiscal Decentralization. In Managing Fiscal Decentralization, ed. E. Ahmad and V. Tanzi, 425-436. London and New York: Routledge.

Tarlton, C. D. (1965). Symmetry and Asymmetry as Elements of Federalism. Journal of Politics, 27(4), 861-874.

Tiebout, C. M. (1956). A Pure Theory of Local Expenditures. Journal of Political Economy, $64,416-424$.

Tillin, L. (2007). Unity in Diversity? Asymmetry in Indian Federalism. The Journal of Federalism, 37(1), 45-67.

Uchimura, H. (2012). Health Development in the Decentralized Health System of the Philippines: Impact of Local Health Expenditures on Health. In Fiscal Decentralization and Development, Experiences of Three Developing Countries in Southeast Asia, ed. H. Uchimura, 73-100. Hampshire: Pargrave Macmillan.

UNDP. (1990). Human Development Report 1990. New York: Oxford University Press.

Watts, R.L. (1999). Comparing Federal Systems. Second edition. Kingston, Canada: Institute of Intergovernmental Relations, Queen's University.

Watts, R.L. (2005). A Comparative Perspective on Asymmetry in Federations. Asymmetry Series, 4, 2-5.

Wehner, J. (2000). Asymmetrical Devolution. Development Southern Africa, 17(6), 249-262.

White, S. (2011). Government Decentralization in the 21st Century, A Literature Review. A Report of the CSIS Program and Crisis, Conflict and Cooperation. Washington, DC: Center for Strategic \& International Studies.

World Bank. (2005). East Asia Decentralizes: Making Local Government Work. Washington DC: The World Bank.

Zhang, T. \& Zou, H. (1998). Fiscal Decentralization, Public Spending, and Economic Growth in China. Journal of Public Economics, 67, 221-240. 